
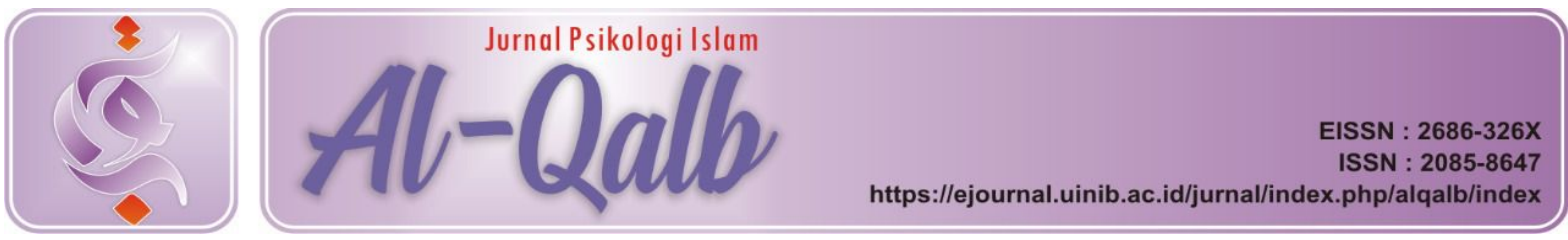

\title{
HARMONISASI MASYARAKAT MENTAWAI
}

Received: $23^{\text {th }}$ September 2018; Revised: $10^{\text {th }}$ October 2018; Accepted: $24^{\text {th }}$ November 2018

\section{Rizal Kurniawan}

UIN Imam Bonjol Padang

Email: rizal0kurniawan@gmail.com
ABSTRAK. Mentawai merupakan salah satu suku yang masih primitif yang masih menyimpan sisa-sisa kehidupan pemburu dan pengumpul. Mereka masih hidup terpisah hidup berkelompok, masih menjalankan agama kepercayaan mereka, memiliki tato sebagai penanda identitas kelompok. Situasi-situasi tersebut menyimpan potensi untuk terjadinya konflik antar kelompok. Namun beberapa dinamikan kehidupan masyarakat mentawai dan nilai budaya yang diwariskan oleh nenek moyang mereka mampu meredam konflik tersebut. Tulisan ini bertujuan untuk mengambarkan beberapa nilai budaya dan dinamika kehidupan masyarakat Mentawai yang dapat meredakan konflik antar kelompok. Studi pustaka digunakan pada penelitian ini. Hasilnya yang didapatkan bahwa nilai gotong royong yang masih diterapkan dalam membangung tempat tinggal, tersedianya transportasi air yang memudahkan mereka untuk melakukan kontak sosial dan perkawinan antar kelompok yang dipraktekkan dan menghukum berat mereka yang membunuh dapat meminimalisir untuk terjadinya konflik.

Kata kunci: Mentawai, harmonisasi, persilangan sosial.

\section{A. PENDAHULUAN}

Mentawai merupakan pulau terpancil yang terletak di barat pulau Sumatra. Kepulauan Mentawai tergabung ke dalam propinsi Sumatra Barat, namun terpisah dengan sistem budaya Minangkabau, karena batas sebelah barat dari budaya minang yang terdapat dalam buku adat adalah garis pantai, jadi terdapat banyak sekali perbedaan antara masyarakat mentawai dengan masyarakat Minangkabau.

Ada beberapa fakta yang menarik di suku Mentawai yang pada dasarnya fakta ini dapat menjadi sumber konflik antar kelompok. Pertama, suku mentawai adalah salah satu suku yang paling kuno di
Indonesia. Diprediksikan bahwa nilai-nilai zaman neolitikum masih terdapat di beberapa daerah mentawai seperti masih mengumpulkan makanan (food gathering), mengolah tanah yang dijadikan ladang (food producing), memelihara binatang sebagai bahan makanan dan sebagai hewan budaya, mengembangkan beberapa kerajinan tangan - yang sangat terkenal pada masyarakat mentawai adalah tato (Munaf, 2001). Suku primitif seringkali diasosiasikan dengan konflik. Stereotipe ini mungkin dibentuk dari sejarah-sejarah pada masa lalu. Masyarakat Mentawai juga masih menganut kepercayaan animisme, misalnya mereka percaya bahwa orang sakit dikarenakan 
gangguan oleh roh jahat. Mereka menggunakan dukun untuk menyembuhkan orang sakit dengan cara mengusir roh dari tubuh orang yang sakit (Schefold, 2014).

Kedua, di Mentawai juga terdapat suku-suku yang hidup memisah dengan kelompok lain. Pada tahun 1980an pemerintah memprogramkan untuk membangun tempat pemukiman di Mentawai. Tetapi kebanyakan suku-suku di Mentawai tidak mau tinggal di pemukiman, mereka lebih memilih untuk tinggal bersama kelompok mereka terpisah dari kelompok yang lain. Di duga terdapat lebih dari 40 kelompok yang menempati empat pulau besar di mentawai. Keberadaan banyak suku berada di suatu daerah berpontensi menimbulkan konflik ketika dipicu oleh persaingan antar kelompok dalam mencapai tujuan, perebutan lahan pertanian salah satu contohnya.

Ke tiga, di Mentawai masih dipraktekkan agama kebudayaan yang diwariskan oleh leluhur mereka Arat Sabulungan, yaitu suatu kepercayaan bahwa segala yang ada di alam mempunyai roh. Bertentangan dengan pemerintah yang menyatakan bahwa di Indonesia hanya ada lima agama yang diakui, sehingga agama Arat Sabulungan ini di larang dipraktekkan. Akibatnya, sering terjadi razia yang dilakukan oleh pihak yang berwenang dalam pemeriksaan praktek Arat Sabulungan di Mentawai. Kondisi ini juga sangat rentan untuk menimbulkan konflik. Bila terjadi kesalahpahaman antara anggota kelompok agama dapat menimbulkan perang kecil yang bersumber pada keagamaan.

Ke empat, di Mentawai juga terkenal dengan tatonya. Pembuatan tato di Mentawai dipengaruhi oleh sistem kebudayaan yang berada di sana. Tato berfungsi sebagai simbol-simbol tertentu dalam status sosial di Mentawai, misalnya untuk menunjukkan kelompok sosial seperti simbol kesukuan, profesi, gender. Tato pada masyarakat mentawai dapat dianalogikan dengan seragam yang berfungsi untuk membedakan satu kelompok dengan kelompok yang lain, yang pada ujungnya dapat meningkatkan kohesivitas antara anggota kelompok. Bila kohesivitas suatu kelompok tinggi sangat memungkinkan untuk menimbulkan ingroup-favoritism yang potensial dalam menimbulkan konflik.

Tidak hanya tato, Identitas sosial masyarakat mentawai mengalami perkembangan seiring dengan perkembangan zaman dan intervensi politik. Identitas masyarakat mentawai dapat dibagi dari banyak hal yang antara lain adalah berdasarkan: uma (rumah besar), klan, lembah asal, mobilitas antar pulau, kampung relokasi, jenis makanan, intelektualitas, agama dan bahasa (Delfi, 2013).

Selain itu, dengan perkembangan zaman, beberapa kelompok masyarakat Mentawai mencari lokasi baru untuk membangun pemukiman yang berbeda dengan mereka yang masih tinggal di daerah yang lama. Beberapa masyarakat telah membangun lokasi ini membentuk identitas baru yang disebut dengan Saimuntei. Dengan identitas baru ini menambah deretan identitas-identitas yang ada di Mentawai. Beragam identitas merupakan sesuatu yang baik, namun dalam suatu waktu juga dapat menjadi sumber konflik. Di tengah perubahan zaman yang semakin cepat kita tidak tahu apa lagi yang akan terjadi. Bisa saja tekanan politik dan ekonomi dapat membentuk identitas baru bagi masyarakat Mentawai.

Namun, pada sisi lain masyarakat mentawai juga mempunyai nilai kebudayaan yang dapat menimalisir terjadinya konflik misalnya, budaya gotong royong, 
menghukum bagi para pembunuh dan pernikahan antar suku.

\section{Konflik dan harmonisasi}

Teori yang pertama yang dipakai pada tulisan adalah toeri yang menjelaskan bagaimana akar konflik dapat terbentuk di masyarakat Mentawai. Untuk menjelaskan fenomena ini digunakan teori identitas sosial. Setelah itu akan dijelaskan pula teori tentang harmonisasi masyarakat Mentawai dengan menggunakan teori persilangan sosial dan kontak sosial.

Teori identitas sosial menjelaskan bagaimana suatu kelompok dapat memberikan harga diri seseorang. misalnya seseorang merasa bangga ketika memakai identitas suatu kelompok Bila seseorang terlalu menganggap baik kelompok yang memberinya rasa nyaman atau kelompok yang memiliki keistemawaan atau kesuksesan dan melihat rendah kelompok lain maka akan membentuk ingroup favoritism. Ingroup favoritism merupakan akar dari terbentuknya streotipe dan diskriminasi yang merupakan sesuatu yang potensial dalam memicu konflik antar kelompok (Sanderson, 2010; Hogg \& Vaughan, 2010).

Selanjutnya, pada bagian dua akan menjelaskan teori harmonisasi yang dapat menimalisir prasangka seseorang. Ada dua teori yang digunakan untuk menjelaskan hal ini yaitu teori persilangan sosial dan kontak sosial. Pada dasarnya tidak ada seseorang yang menyandang hanya satu status sosial. Seorang individu yang berada dalam suatu kelompok majemuk akan memiliki persamaan identitas dengan anggota kelompok lainnya. Dari pertemuan persilangan identitias ini akan membentuk beberapa kesamaan yang dapat menjadi dasar untuk mereduksi konflik antar kelompok. Faturochman (2007) dalam kongres Himpsi ke 10 mengambarkan tipe persilangan kategori sederhana menjadi empat situasi di mana dua kelompok yang memiliki identitas berbeda saling bertemu. Situasi pertama terjadi ketika ke dua kelompok sama-sama ingin mengedepankan ingorup kelompoknya masing-masing. Situasi ke dua terjadi ketika kelompok pertama mengedepankan ingroup dan kelompok ke dua mengedepankan outgroup. Pada situasi ketiga terjadi ketika kelompok pertama mengedepankan outgroup dan kelompok pertama mengedepankan ingroup. Pada situasi keempat terjadi ketika kedua kelompok sama-sama mengedepankan outgroup. Konsep persilangan sosial menunjukkan bahwa pada situasi ke dua dan ke tiga, kelompok akan lebih cendrung inklusif, karena setiap kelompok ini terdapat titik temu yang positif yang dapat menyatukan kelompok yang berbeda. Pada situasi pertama dan ke empat, kelompok akan lebih cendrung eklusif, karena tidak terdapat titik temu antar kelompok sehingga dalam kondisi ini memungkinkan untuk memunculkan konflik. Masing-masing kelompok akan mempertahankan nilai kelompoknya. Sehingga dalam penggunaan konsep ini untuk menyatukan dua atau lebih kelompok yang berbeda adalah dengan mencari kesamaan yang dimiliki oleh setiap kelompok.

Selain konsep persilangan kategori, untuk melihat proses harmonisasi antar kelompok juga bisa dengan menggunakan konsep kontak sosial. Hipotesis kontak yang dikemukan oleh Allport (dalam Dovido. 2003) mentayakan bahwa pertemuan antara anggota dua kelompok dapat menurunkan prasangka. Dovidio (2003) menyebutkan untuk terjadinya penurunan prasangka setidaknya harus ada suatu syarat dan mekanisme tertentu dalam kontak sosial 
untuk menghasilkan sesuatu perubahan yang positif. Persyaratan yang harus ada di dalam proses kontak sosial adalah kesetaraan status, kerja sama, tujuan bersama, norma pendukung, interaksi personal dan kesempatan pertemanan. Persyaratan ini akan membentuk mekanisme yang membuat seseorang akan mengevaluasi dan melakukan persepsi ulang pada objek yang dijadikan stereotipe. Aktivitas perubahan streotipe, proses kontak sosial harus terpenuhi paling tidak satu nilai yang ada pada tiap-tiap proses untuk membuat perubahan sikap pada seseorang. Bila ada nilai tersebut yang tidak ada yang terpenuhi dalam suatu proses maka evaluasi dan perubahan persepsi tidak akan terwujud.

\section{B. PEMBAHASAN}

\section{Prinsip gotong royong pada masyarakat mentawai}

Masyarakat mentawai mempunyai uma, yaitu rumah besar yang menjadi tempat penginapan bersama, tempat penyimpanan pusaka serta dianggap suci oleh setiap suku. Uma ini sengaja dibangun oleh nenek moyang mereka di pingiran sungai besar untuk mempermudah sumber air, transportasi dan pertanian. Uma merupakan tempat yang penting bagi masyarakat mentawai. Ia merupakan tempat berkumpul, tempat penyembuhan orang sakit. Untuk tempat beberapa ritual. Uma memiliki pemimpin untuk melakukan jalannya suatu ritual yang disebut dengan rimata (Schefold, 2014).

Dengan kondisi uma (tempat utama para anggota suku untuk berkumpul) seperti yang berdiri di pinggir sungai, maka transportasi utama mereka adalah perahu. Kontak sosial antara suku terjadi di sini, dimana suku yang berdekatan saling membantu dalam pembuatan perahu, dari penebangan kayu sampai pada proses pembuatan.

Selain pembuatan perahu, kontak sosial juga terjadi ketika antar suku saling membantu dalam membangun rumah. Sehingga kelompok yang telah terbantu akan membalas budi ketika kelompok yang lainnya butuh bantuan.

Dalam kontek sejarah, kontak sosial telah terjadi sejak masyarakat Mentawai mengusir belanda dari pulau mereka. Mereka bekerja sama untuk mempertahankan daerah mereka dari Belanda. Maka bila dilihat dari konsep kontak sosial, ke dua tahap dari beberpa contoh tadi telah terpenuhi, seperti para yang ahli menebang kayu bekerja sama dalam mencari kayu yang memiliki kualitas yang baik untuk membuat kapal atau bahan utama uma. Memiliki tujuan yang sama dalam bergotong royong. Sehingga sangat memungkinkan mereka akan mengubah persepsi dan evaluasi seseorang pada kelompok lainnya. Pada kasus bekerja sama mengusir Belanda contohnya, pada tahap syarat proses kerja sama telah terjadi, dalam mekanisme antara terdapat afeksi, karena mereka merasa dijajah dan harus melakukan perlawanan untuk membebaskan mereka melalui kerja sama dengan kelompok lain sehingga akan terjadi peleburan identitas sosial setiap kelompok.

Kasus menarik justru ketika terjadi gempa dan tsunami di Mentawai. Setiap kelompok harus dievakuasikan ke tempat aman, ada berita yang menyatakan bahwa pemerintah setempat kesulitan dalam merelokasi para pengungsi karena dapat menimbulkan konflik (Kompas, 8 November 2010). Yang menjadi pertanyaan adalah seberapa efektifkah kontak sosial yang terjadi selama ini kalau memang hipotesis kontak dapat diaplikasikan di Mentawai? 


\section{Gempa bumi dan potensi konflik}

Terdapat kurang lebih 40 suku yang berada di Mentawai yang tersebar luas dan menempati empat pulau besar (Sihombing, 1978). Dalam sebarannya itu tentu ada yang dekat dan ada yang jauh. Karena transportasi yang digunakan hanya perahu, kontak sosial dengan kelompok jauh sulit dilakukan, sehingga proses penilaian negatif kelompok lain masih bisa terjadi.

Dalam kasus tsunami di atas adanya proses penyatuan dua puluh enam dusun dalam suatu tempat. Tentu setiap dusun ada yang belum saling kenal. Masih mungkin bisa memunculkan prasangka apalagi ditambah dengan stres pasca trauma yang masih mereka rasakan dan kesulitan untuk mendapatkan sumber air atau makanan masih berkompetisi karena proporsi jumlah orang yang membutuhkan tidak sebanding dengan sumber yang ada. Semuanya ini adalah potensi-potensi konflik, merupakan langkah yang tanggap ketika harus memikir ulang untuk menyatukan beberapa kelompok ini dalam suatu kawasan pengungsian.

Solusi yang tepat untuk memaksimalkan proses kontak adalah dengan menambahkan alat transportasi, sehingga dapat memungkinkan melakukan kontak dengan kelompok yang jauh. Hal ini penting karena masyarakat tradisional mentawai masih menyimpan trauma dengan orang kulit putih akibat dari trauma kolonialisme (Delfi, 2005). Dengan banyak melakukan kontak dengan kelompok lain apalagi dengan orang-orang di pulau lain dapat mereduksi prasangka terhadap kulit putih, karena juga mengingat bahwa pulau Mentawai mempunyai daya tarik wisata yang tinggi, pandangan terhadap kulit putih dapat problem serius dalam pengembangan parawisata.

\section{Pernikahan antar suku sebagai nilai budaya}

Suku Mentawai menganut sistem patrilinear, istri mengikuti suami. Suku mentawai juga menerapkan bahwa tidak boleh melakukan perkawinan dengan anggota suku yang sama, mereka harus memilih istri atau suami yang berbeda dengan suku mereka. Dengan begitu, istri yang mengikuti suami akan menyandang suku suami setelah mereka menikah.

Dalam pandangan teori persilangan kategori, kegiatan ini merupakan suatu fenomena yang sangat menarik. Proses persilangan terjadi pada situasi ke dua dan ke tiga pada penjelasan di atas. Di mana dua yang berbeda akan membentuk satu kesamaan baru dalam suatu ikatan perkawinan antar suku. Dalam dinamikanya akan membentuk banyak sekali persilangan antar suku yang tersebar di Pulau Mentawai. Dengan persamaan ini dapat menimalisir terjadinya konflik, karena setiap suku mempunyai anggota keluarga pada suku yang lain.

Yang menjadi pertanyaan yang sangat penting untuk mengevaluasi fenomena ini adalah, apakah ketika suami meninggal, si istri kembali lagi bergabung dengan kelompok lamanya?

Munaf (2001) menyatakan bahwa ketika sepasang suami istri mengikat sebuah janji perkawinan, mereka akan disimbolkan dengan sebuah tato dengan motif pulaingiania. Bila suami meninggal maka istri akan tetap tinggal di suku suami tersebut dengan adanya identitas tato yang masih menempel pada si istri. Bila sang istri ingin menikah lagi, yang diutamakan untuk menjadi suaminya adalah seseorang yang mempunyai suku yang sama dengan suaminya yang telah meninggal, jadi tidak akan terjadi perpindahan suku. 
Namun Delfi (2005) menyatakan hal yang berbeda. Si istri bila ditinggal mati atau cerai oleh suami, maka istri akan kembali pada suku asalnya. Namun dalam referensi ini tidak membahas mengenai tato yang disimbolkan ketika pernikahan. Menurut analisis penulis tato (nilai budaya) merupakan kunci dari perbedaan ini, karena kelompok yang hidup di pemukiman dan yang masih hidup berkoloni di hutan mempunyai berbedaan pemahaman nilai budaya.

\section{Konteks baru}

Dengan perkembangan sistem sosial dan politik di Sumatra Barat, dan setelah penetapan Peraturan Daerah untuk melakukan penyatuan kebudayaan nilai yang ada di Minangkabau, menimbulkan gesekan baru di Mentawai. Arat sulubungan yang merupakan sistem kepercayaan mereka akan terancam karena lahirnya masyarakat Mentawai menolak Perda tersebut karena menurut mereka tidak cocok dengan kehidupan mereka. Dalam penolakannya terhadap Perda tersebut, masyarakat Mentawai terpecah menjadi dua. Ada di antara mereka menolak dengan membuat peraturan bandingan dengan Perda yang cocok dengan nilai dan budaya mereka yang disebut dengan Langgai. Kelompok lainnya yang kontra dengan Perda Sumatra Barat tidak setuju dengan penetapa Langgai ini. Menurut mereka Langgai membawa mereka kembali ke masa lalu yang masih tertinggal. Kelompok ke dua ini terdiri dari kelompok elit yang telah hidup mengikuti budaya modern. Dalam situasi ini masnyarakat Mentawai membentuk kelompok sosial baru antara mereka yang menolak dan menerima Langgai.

Selain itu kelompok baru juga terbentuk akibat dari pro dan kontra pada pembangunan tempat tinggal baru. Kelompok pertama meneriam tempat tinggal baru dan kelompok ke dua menolaknya. Dari segi makanan mereka juga membentuk kelompok sosial baru yaitu mereka yang memakan sagu dan mereka yang memakan nasi. Tidak menutup kemungkinan kelompok sosial akan bertambah banyak seiring dengan dinamika sosial yang terus terjadi.

Dengan banyaknya kelompok sosial yang terbentuk, akan membesarkan peluang untuk terjadinya persaingan antar kelompok. Persaingan ini akan menghasilkan dua situasi yaitu konflik dan kerja sama. Persaingan antar kelompok yang dapat menimbulkan konflik, bila dilihat dari teori identitas sosial, terjadi ketika suatu kelompok merasa fanatik dengan kelompoknya dan melihat kelompok lain dengan pandangan yang inferior. Tingginya fanatisme terhadap kelompok sendiri akan memunculkan potensi baru untuk terjadinya konflik. Untuk mengatasi hal tersebut terjadi, pandangan terlalu fanatik terhadap kelompok sendiri haruslah dihindarkan dengan melakukan kontak sosial dan persilangan sosial yang terdapat di dalam kebudayaan Mentawai.

\section{SIMPULAN}

Beberapa nilai kebudayaan mentawai mempunyai implikasi yang cukup potensial untuk mencegah terjadinya konflik antar suku di Pulau Mentawai. Di samping kebudayaan tato yang contohkan dalam perkawinan silang tadi, juga terdapat kebudayaan unik lainnya yang mampu keharmonisan antar kelompok, seperti kepercayaan salubungan, yang mempercayaai bahwa setiap sesuatu mempunyai roh yang harus di hormati (Munaf, 2005). Sehingga mereka sangat memperhatikan lingkungan, seperti 
penebangan liar, pembukaan lahan baru untuk pertanian dan sebagainya. Dengan menghormati alam dan lingkungan ini, tentu menjadi suatu dimensi penting untuk menghindari konflik lahan, karena salah sumber dari konflik lingkungan ada lahan (land) (Bechtel, 2002). Dalam menebang pohon, masyarakat Mentawai memiliki aturan adat seperti mendorong masyarakat untuk menanam kayu keras sehingga menjaga keseimbangan ekosistem juga mereka yang membuka hutan tidak boleh dengan cara pembakaran yang dapat merusak tanaman-tanaman liar dan hewan yang hidup di dalamnya, tidak mematikan pohon yang berguna dan tidak menebang habis pohon yang ada (Senatung, 2005).

Selain itu kebudayaan mentawai juga mempunyai sangsi bagi para pembunuh, yaitu menanam seratus batang kelapa (Delfi, 2005). Konsep ini juga dapat dijadikan dimensi budaya yang potensial dalam mengurangi terjadinya kekerasan.

Yang justru menjadi masalah adalah kelompok yang hidup dengan para pendatang. Kelompok ini lebih modern di bandingkan dengan kelompok yang masih hidup berkoloni di hutan. Dengan benturan beberpa nilai kehidupan, seperti penggunaan teknologi, heterogenitas kelompok membuat nilai kebudayaan mentawai mulai ditinggalkan dengan ditemukan bahwa telah banyak masyarakat mentawai tidak menguasai tari Langgai yang merupakan tari khas Mentawai (Kompas, 24 Juni 2010). Perhatian pemerintah juga turut berperan dalam pudarnya budaya mentawai ini (Kompas,17 November 2008) yang tidak bekerja sama dengan pihak setempat, juga pengaruh dari kurangnya pengajaran budaya mentawai dalam seting pendidikan (Kompas, 14 November 2008).

Di sisi lain, masyarakat Mentawai melakukan penolakan pada Peraturan
Daerah Sumatra Barat yang mereka rasakan dapat menganggu adat dan identitas mereka. Masyarakat Mentawai membuat peraturan sendiri yang disebut dengan Langgai. Namun ada pula mereka yang menolak Langgai, yang terdiri dari kelompok elit, karena membawa mereka ke zaman yang dulu. Ke dua kelompok tersebut tetap menolak Perda Sumatra Barat namun dengan reaksi yang berbeda, kolompok elit melakukan penolakan dengan terbuka seperti melakukan protes dan demonstrasi dan masyarakat Mentawai menolaknya dengan sembunyi seperti sindiran, menjadi gunjingan dan pura-pura tidak tahu (Delfi, 2005).

Untuk mencari solusi dari permasalahan ini dibutuhkan kerja sama masyarakat dan pemerintah dalam melestarikan kebudayaan yang merupakan aset yang sangat berharga yang dimiliki oleh bangsa. Melalui sosialisasi, kerja sama dan menerapkannya di dalam dunia pendidikan, nilai dan budaya di Mentawai dapat terjaga dengan. Selain menjadi kekayaan bangsa, beberapa kebudayaan Mentawai juga menyimpan nilai-nilai yang dapat membuat masyarakat tersebut hidup damai dalam harmoni.

\section{DAFTAR KEPUSTAKAAN}

Bechtel, B. R. (2002). Hand Book of Environmental Psychology. New York: Willey.

Delfi, M. (2005). Dari Desa ke Rangai: Resistensi dan Identitas Orang Mentawai. Tesis Fakultas Ilmu Budaya UGM. 323, 6 del d

Delfi, M. (2013). "Kaipa Pulaggajatnu”: Wacana kementawaian di bumi Sikerei. 
Disertasi. Universitas Gadja Mada. Yogyakarta.

Dovidio, F. A. (2003). Intergroup Contact: The Past, Present and The Future. Group Process and Intergroup Relation. 6(1), 5-21.

Faturochman. (2007). Model-model Psikologi Kebhinekatunggalikaan dan Penerapannya di Indonesia. Paper Temu Ilmiah dan Kongres X Himpsi. $\mathrm{h}$. 8.

Hogg, M. A., \& Vaughan, G. M. (2010). Essentials of Social Psychology. Pearson: Essex.

Kompas (14 November 2008). Mulok Budaya Mentawai Belum Juga Terwujud. Situs (kompas.com).

Kompas (17 November 2008). Pudarnya Budaya Mentawai. Situs (kompas.com).

Kompas (24 Juni 2010). Kebudayaan Mentawai Mulai Ditinggalkan. Situs (kompas.com).

Kompas (8 November 2010). Relokasi Korban Rawan Konflik. Situs (kompas.com).

Munaf, Yarni. (2001). Kajian Semiotik dan Mitologis Terhadap Tato Masyarakat Tradisional Kepulauan Mentawai. Jakarta: Pusat Bahasa Departemen Pendidikan Nasional.

Sanderson, C. A. (2010). Social Psychology. Danver: Willey and Sons.
Schefoldf, R. (2014). Aku dan Orang Sikudei: Menjaga Jiwa di Rimba Mentawai. Kompas: Jakarta.

Senatung. (2005). Kearifan lokal masyarakat Mentawai dalam pengelolaan sumber daya hutan dan lingkungan di Pulau Siberut Propinsi Sumatra Barat. Tesis. Universitas Gadjah Mada. Yogyakarta. 